\title{
Spiders from Oksunbong in Chungcheongbuk-do, Korea
}

\author{
Moon-Soon $\mathrm{Im}^{1}$, Sue-Yeon Lee ${ }^{2}$, Jong-Kook Jung ${ }^{2}$, Han-Mo Koo ${ }^{3}$, Jung-Sun Yoo $^{4}$ and Seung-Tae Kim,* \\ ${ }^{1}$ College of Life and Environmental Sciences, Konkuk University, Seoul 143-701, Korea \\ ${ }^{2}$ Entomology Program, Deparment of Agricultural Biotechnology, Seoul National University, Seoul 151-921, Korea \\ ${ }^{3}$ Department of Plant Resources, Kongju National University, Yesan 340-802, Korea \\ ${ }^{4}$ Department of Strategic Planning, National Institute of Biological Resources, Incheon 404-170, Korea \\ ${ }^{5}$ Research Institute for Agriculture and Life Sciences, Seoul National University, Seoul 151-921, Korea \\ *Correspondent: stkim2000@hanmail.net
}

\begin{abstract}
Spider fauna of Oksunbong located in Jecheon City, Chungcheongbuk-do, was surveyed provisionally from May to September in 1998. A total of 58 species of 40 genera in 18 families from 301 individuals of spiders were identified. Species richness of each family, there were 10 Araneid species (17.2\%), followed by 9 Theridiid species (15.5\%), and 8 Tetergnathid speices (13.8\%). Zoogeographically, spider fauna of Oksunbong represented 1 cosmopolitan species (1.7\%), 2 holarctic region species (3.4\%), and 7 palearctic region species $(12.1 \%)$. However, Korean endemic species were not collected during this survey. Thus it is suggested that spider fauna of Oksunbong was under northern regional influence.
\end{abstract}

Keywords: fauna, Korea, list, Oksunbong, spider

\section{INTRODUCTION}

Up to date detailed qualitative studies of mountainous spiders in Chungcheong area have not yet been conducted properly. On a global and regional scale, mountains usually maintain high species richness with some rare species because they are not much disturbed by human activity compared to other ecosystems. In view of the growing importance of distribution data of organisms for conservation at many scale, biota will depend heavily on compiled data including many ecological factors such as time, space, habitat type, community structure, biodiversity, functional guild and so on. Spiders, one of the main arthropods which show high relative abundance, ease of collection, and high biodiversity in habitat preferences and foraging strategies, allows for effective monitoring of site differences (Yen, 1995). This survey was conducted in Oksunbong situated in Chungcheongbuk-do, as a serial work to understand spider fauna of Korean mountains through qualitative monitoring and establishing regional inventory.

\section{Materials ANd Methods}

\section{Study site}

Oksunbong is located in Jecheon City, Chungcheong- buk-do and situated at $128^{\circ} 14^{\prime} \mathrm{E}, 35^{\circ} 56^{\prime} \mathrm{N}$ with $283 \mathrm{~m}$ above sea level(Fig. 1). Oksungbong is located along the western edge of Lake Cheongpungho and belonging to Woraksan National park.

\section{Survey method and schedule}

Survey was made from along the South-east and East ridges to peak. Sweep net (38 cm in diameter) and hand picking with naked eyes were used for the collection of spiders inhabiting on the plant stands above ground. Spiders active on ground surface were collected using sieve. Sieving was made with plant litters every $300 \mathrm{~m}$ interval along the survey route. Survey was made 5 occasions (21 May, 15 June, 5 July, 22 August and 25 September) in 1998.

\section{Identification}

The spiders collected were identified using a stereoscopic microscope (Nikon smz 800) and provisional keys (Paik, 1978; Chikuni, 1989; Namkung, 2001; Ono, 2009). Checklist by Namkung et al. (2009) and catalogue of Platnick (2012) were used for species names and to take into consideration recent changes made to scientific names. Specimens collected during the study period were prepared as immersion specimen using $80 \%$ ethylalcohol and were deposited in Konkuk University. 


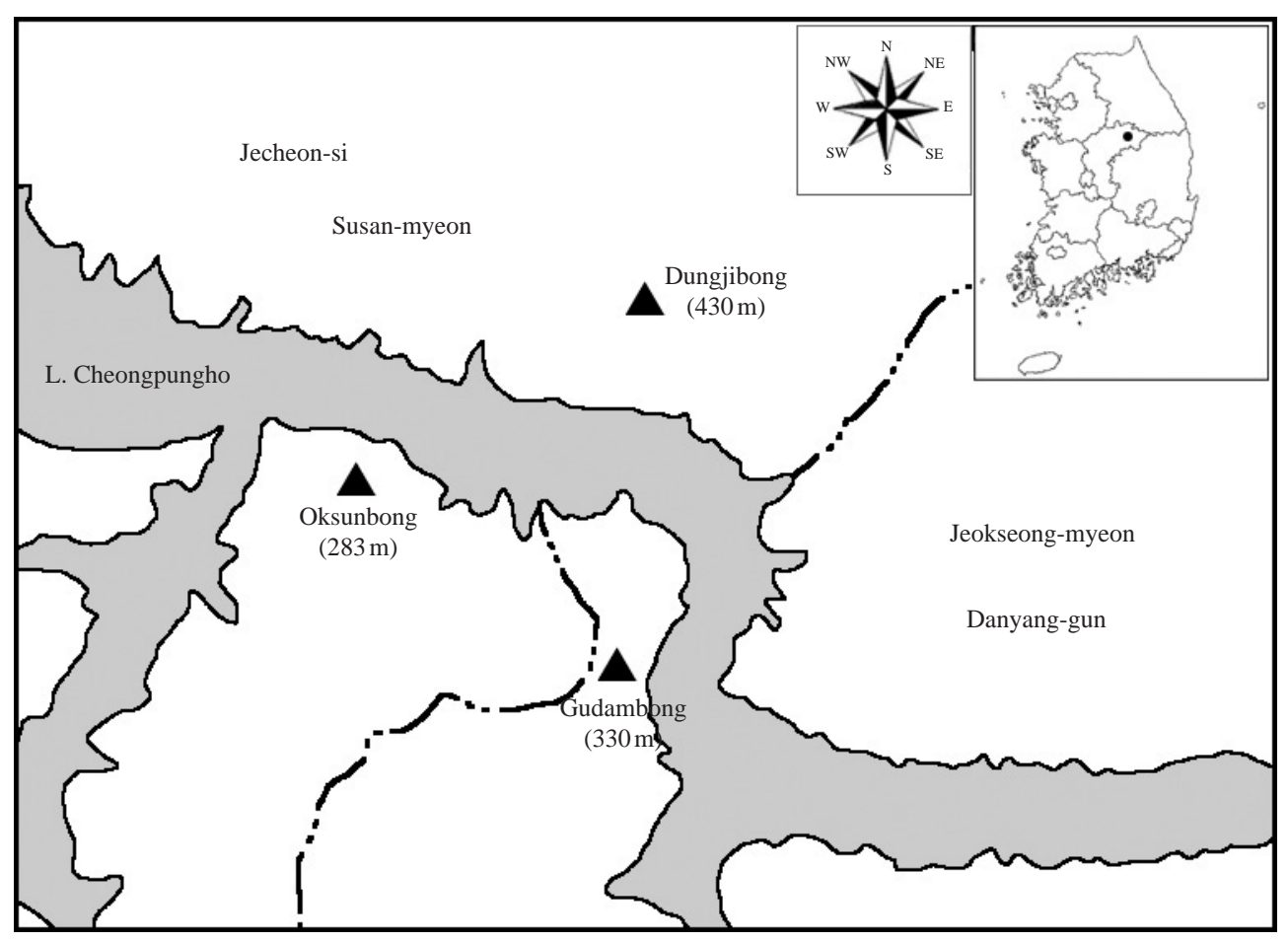

Fig. 1. Location of Oksunbong in Chungcheongbuk-do.

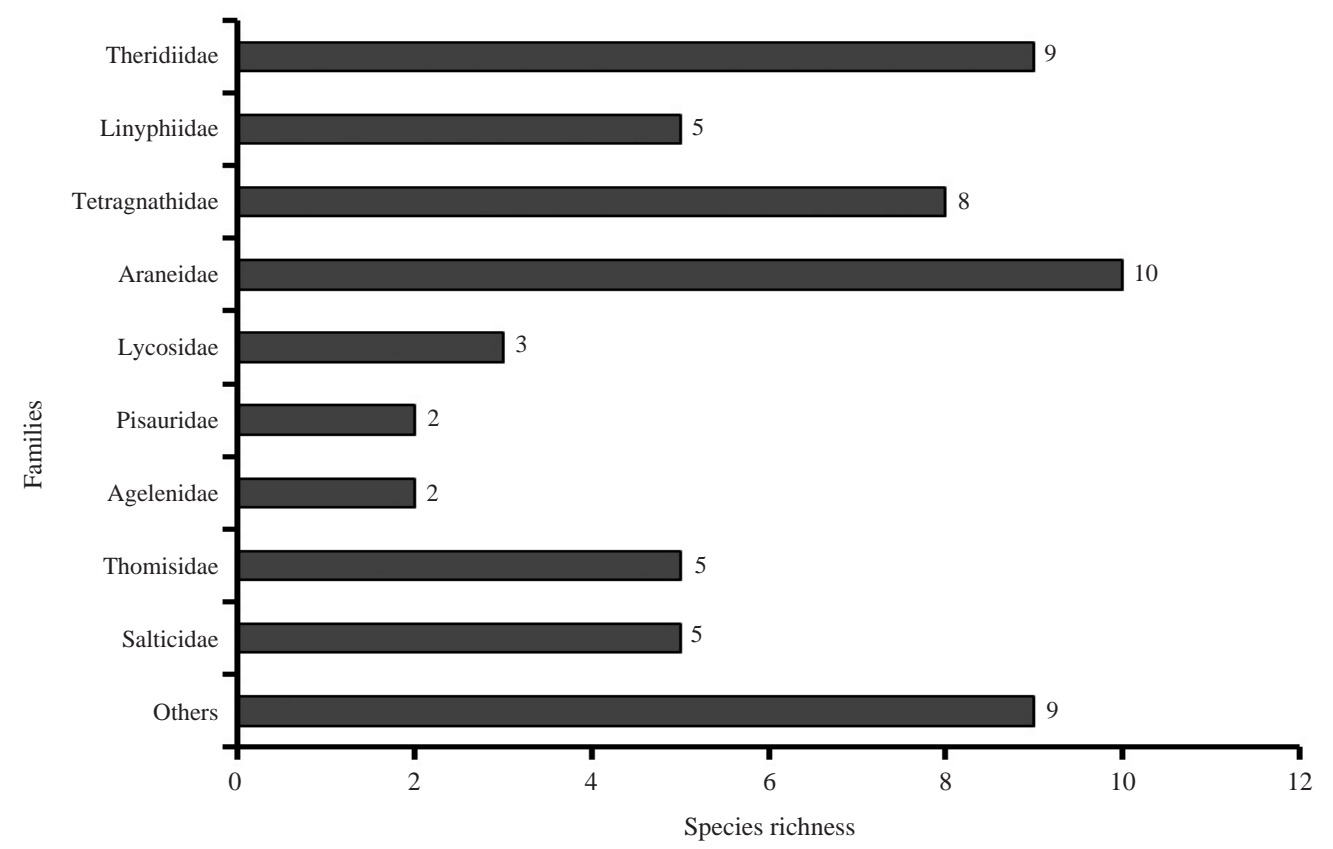

Fig. 2. Species richness of each family.

\section{Results AND Discussion}

A total of 58 species which belong to 40 genera of 18 families were identified from 301 individuals of spiders (Table 1). In terms of species richness of each family, there were 10 Araneid species (17.2\%), followed by 9 Theridiid species $(15.5 \%)$, and 8 Tetergnathid species 
Table 1. List of spider taxa in Oksunbong.

\begin{tabular}{|c|c|c|c|c|c|c|c|}
\hline \multirow{2}{*}{ Family } & \multirow{2}{*}{ Korean name } & \multirow{2}{*}{ Species } & \multicolumn{5}{|c|}{ Collecting date } \\
\hline & & & $5 / 21$ & $6 / 15$ & $7 / 5$ & $8 / 22$ & $9 / 25$ \\
\hline PHOLCIDAE & 산유령거미 & Pholcus crypticolens & & & 1 & 2 & 1 \\
\hline ULOBORIDAE & 손짓거미 & Miagrammopes orientalis & 1 & & & & 1 \\
\hline \multirow[t]{9}{*}{ THERIDIIDAE } & 꼬리거미 & Ariamnes cylindrogaster & & & 1 & & 6 \\
\hline & 안장더부살이거미 & Neospintharus fur & & & & & 1 \\
\hline & 점박이꼬마거미 & Parasteatoda japonica & & & & & 2 \\
\hline & 석점박이꼬마거미 & Parasteatoda kompirensis & & 1 & & & \\
\hline & 큰종꼬마거미 & Parasteatoda tabulata & 1 & & 1 & & \\
\hline & 말꼬마거미 & Parasteatoda tepidariorum & & 5 & 24 & 2 & \\
\hline & 넓은잎꼬마거미 & Takayus latifolius & 1 & & & & \\
\hline & 넉점꼬마거미 & Takayus takayensis & & 2 & & & \\
\hline & 등줄꼬마거미 & Theridion pinastri & 1 & & 2 & & \\
\hline \multirow[t]{5}{*}{ LINYPHIIDAE } & 흑갈풀애접시거미 & Hylyphantes graminicola & & & & & 1 \\
\hline & 쌍줄접시거미 & Neriene limbatinella & & & & & 2 \\
\hline & 농발접시거미 & Neriene longipedella & 1 & & & & \\
\hline & 고무래접시거미 & Neriene oidedicata & 2 & & & & \\
\hline & 테두리접시거미 & Neriene radiata & & & & 1 & \\
\hline \multirow[t]{8}{*}{ TETRAGNATHIDAE } & 꼬마백금거미 & Leucauge celebesiana & & 4 & 13 & & \\
\hline & 왕백금거미 & Leucauge magnifica & & & & 2 & \\
\hline & 금빛백금거미 & Leucauge subgemmea & & & & 3 & \\
\hline & 가시다리거미 & Menosira ornata & & & & & 3 \\
\hline & 병무늬시내거미 & Metleucauge kompirensis & & & & 1 & \\
\hline & 큰배갈거미 & Tetragnatha extensa & 7 & & & & \\
\hline & 민갈거미 & Tetragnatha maxillosa & & & & 1 & \\
\hline & 장수갈거미 & Tetragnatha praedonia & 6 & 6 & 2 & 4 & 1 \\
\hline NEPHILIDAE & 무당거미 & Nephila clavata & & & 6 & & \\
\hline \multirow[t]{10}{*}{ ARANEIDAE } & 호랑거미 & Argiope amoena & & 3 & 1 & & \\
\hline & 긴호랑거미 & Argiope bruennichi & & 3 & 1 & 4 & \\
\hline & 여섯혹먼지거미 & Cyclosa laticauda & & & & & 1 \\
\hline & 여덟혹먼지거미 & Cyclosa octotuberculata & 5 & & 3 & & 5 \\
\hline & 넷혹먼지거미 & Cyclosa sedeculata & & 2 & & & \\
\hline & 귀털거미 & Mangora herbeoides & & 6 & & & \\
\hline & 검은테연 두어리왕거미 & Neoscona melloteei & & & & 2 & \\
\hline & 어리집왕거미 & Neoscona pseudonautica & & & & 4 & 4 \\
\hline & 적갈어리왕거미 & Neoscona punctigera & & & 1 & & \\
\hline & 지이어리왕거미 & Neoscona scylla & 4 & 7 & 3 & 5 & \\
\hline \multirow[t]{3}{*}{ LYCOSIDAE } & 별늑대거미 & Pardosa astrigera & 11 & 3 & 2 & & 5 \\
\hline & 중국늑대거미 & Pardosa hedini & 4 & & 1 & & \\
\hline & 좀늑대거미 & Pirata procurvus & 1 & & & & \\
\hline \multirow[t]{2}{*}{ PISAURIDAE } & 황닷거미 & Dolomedes sulfureus & 1 & & 3 & 1 & 3 \\
\hline & 아기늪서성거미 & Pisaura lama & 1 & 2 & & 1 & 7 \\
\hline OXYOPIDAE & 아기스라소니거미 & Oxyopes licenti & & 8 & 1 & & \\
\hline CTENIDAE & 너구리거미 & Anahita fauna & & 2 & & & \\
\hline \multirow[t]{2}{*}{ AGELENIDAE } & 들풀거미 & Agelena silvatica & & 4 & 4 & 2 & 5 \\
\hline & 타래풀거미 & Allagelena difficilis & & & & 2 & \\
\hline DICTYNIDAE & 잎거미 & Dictyna felis & 1 & & & & \\
\hline COELOTIDAE & 한국깔때기거미 & Pireneitega spinivulva & & & 3 & & 2 \\
\hline MITURGIDAE & 어리염낭거미속 일종 & Cheiracanthium sp. & & & & & 1 \\
\hline PHILODROMIDAE & 금새우게거미 & Philodromus auricomus & 1 & & & & \\
\hline \multirow[t]{5}{*}{ THOMISIDAE } & 꽃게거미 & Ebrechtella tricuspidata & 7 & 8 & 1 & & \\
\hline & 줄연두게거미 & Oxytate striatipes & & & & 1 & 1 \\
\hline & 사마귀게거미 & Phrynarachne katoi & & & 1 & & \\
\hline & 불짜게거미 & Synema globosum & 2 & 1 & & & \\
\hline & 대륙게거미 & Xysticus ephippiatus & & 4 & & & \\
\hline \multirow[t]{5}{*}{ SALTICIDAE } & 산길깡충거미 & Asianellus festivus & & & & & 1 \\
\hline & 털보깡충거미 & Carrhotus xanthogramma & & 2 & & & \\
\hline & 되니쓰깡충거미 & Plexippoides doenitzi & & & 1 & & \\
\hline & 어리개미거미 & Synagelides agoriformis & & & 1 & & \\
\hline & 검은날개무늬깡충거미 & Telamonia vlijmi & & 1 & 1 & & \\
\hline
\end{tabular}



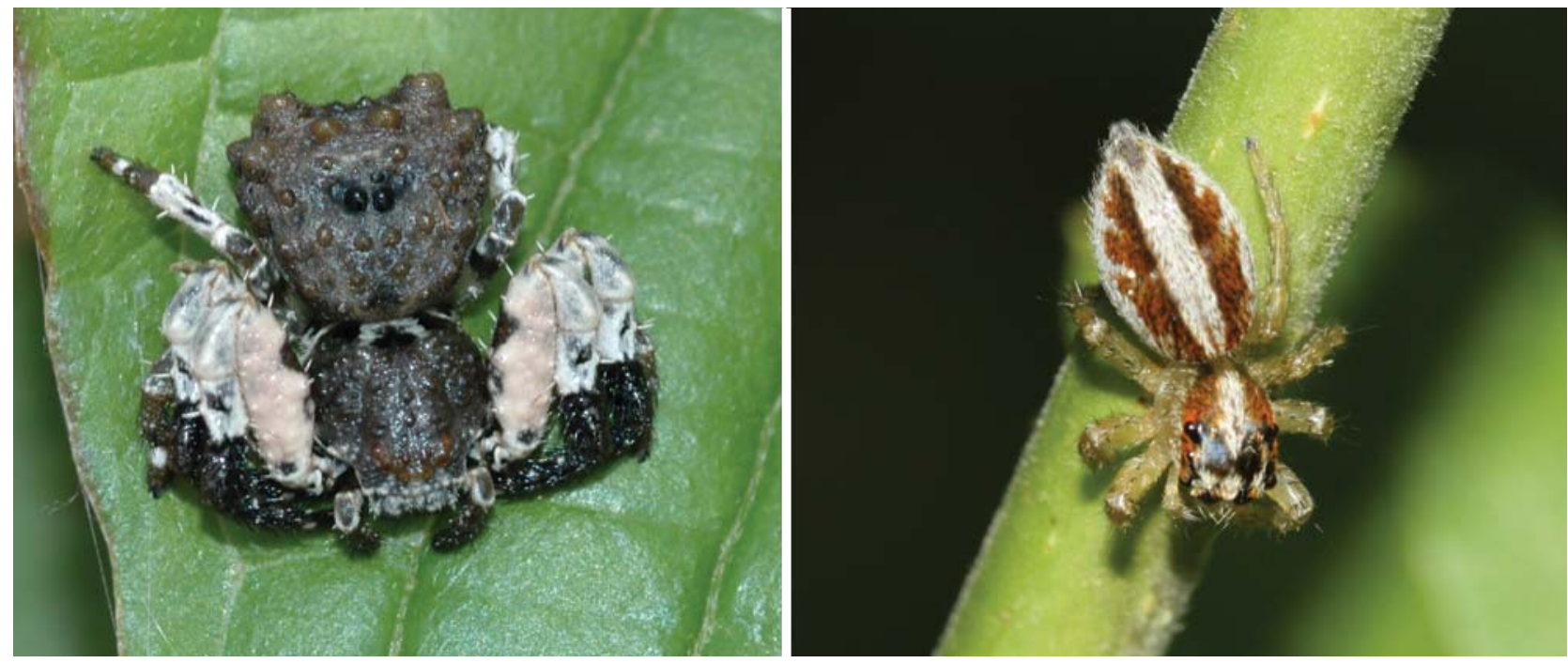

Fig. 3. Females of Phrynarachne katoi (left) and Plexippoides doenitzi (right).

(13.8\%) (Fig. 2). Among the collected spiders, Phrynarachne katoi of Thomisidae (Paik, 1976; Paik, 1979; Namkung, 1980) and Plexippoides doenitzi of Salticidae (Paik and Woo, 1970; Paik, 1980; Kim and Yoo, 1996; Kim et al., 1987) are rare species with narrow distribution range (Fig. 3). Zoogeographically, spider fauna of Oksunbong represented 1 cosmopolitan species (1.7\%; Parasteatoda tepidariorum), 2 holarctic region species (3.4\%; Neriene radiata and Parasteatoda tabulata) and 7 palearctic region species (12.1\%; Argiope bruennichi, Asianellus festivus, Carrhotus xanthogramma, Ebrechtella tricuspidata, Hylyphantes graminicola, Synema globosum and Theridion pinastri) without Korean endemic species by this survey. Thus it is suggested that spider fauna of Oksunbong was under northern regional influence. Van der Merwe et al. (1996) and Churchill (1997) argued that spiders operate as a dominant predator group which can influence the structure of terrestrial invertebrate communities. In the case of spiders, therefore, continuous monitoring in mountains will become important data for the general understanding and use of the various traits of spiders. This survey provides a past collected inventory of mountainous spiders and information regarding the region's biodiversity. Thus the results will not only useful for the effective management and long-term use of national biological resources but also become a highly important data for the preservation of biodiversity based on changes in distribution over time and space.

\section{REFERENCES}

Chikuni, Y. 1989. Pictorial Encyclopedia of Spiders in Japan. Kaisei-sha Publ. Co., Tokyo 310 pp.
Churchill, T.B. 1997. Spiders as ecological indicators: an overview of Ausralia. Mem. Mus. Victoria 56:331-337.

Kim, J.P. and J.S. Yoo. 1996. The spider fauna of Mt. Yebongsan, Kyunggi-do, Korea. Korean Journal of Soil Zoology 1(2):110-119.

Kim, J.P., J. Namkung and J.R. Jun. 1987. On the vertical distribution of spider community in Mt. Hallasan, Isalnd Chejudo, Korea. Korean Arachnology 3(2):117-127.

Namkung, J. 1980. The spider fauna of Mt. Joryeong Area, Korea. Korean Journal of Entomology 10(2):33-42.

Namkung, J. 2001. The spiders of Korea. Kyo-Hak Publishing Co., Seoul 648 pp.

Namkung, J., J.S. Yoo, S.Y. Lee, J.H. Lee, W.K. Paek and S.T. Kim. 2009. Bibliographic Check list of Korean Spiders (Arachnida: Araneae) ver.2010. Korean Nature 2: 191-285.

Ono, H. 2009. The Spiders of Japan with keys to the families and genera and illustrations of the species. Tokai Univ. Press, Kanagawa xvi+739 pp.

Paik, K.Y. 1976. Report on the scientific survey of Bulyeonga Valley, 4. Korean Association of Nature Conservation 10:82-90.

Paik, K.Y. 1978. Araneae. Illustr. Fauna Flora Korea 21:1548.

Paik, K.Y. 1979. Spider Fauna of Mt. Hwanghak. Bulletin of the Korean Association for Conservation of Nature 1:69-285.

Paik, K.Y. 1980. Spider Fauna of Mt. Geumo. Report on the Natural Resources of Mt. Geumo. Gyeongsangbuk-do. pp. 43-53.

Paik, W.H. and K.S. Woo. 1970. Spiders from Mt. Jiri. Korean Journal of Plant Protection 9:103-104.

Platnick, N.I. 2012. The world spider catalog, version 12.5. American Museum of Natural History [Available from: 
online at http://research.amnh.org/entomology/spiders/ catalog/index.html.].

Van der Merwe, M., A.S. Dippenaar-Schoeman and C.H. Scoltz. 1996. Diversity of ground-living spiders at Ngome State Forest, KwaZulu/Natal: a comparative survey in indigenous forest and pine plantation. Afr. J. Ecol. 34: 342-350.
Yen, A.I. 1995. Australian spiders: An opportunity for conservation. Records of the Western Australian Museum Supplement 52:39-47.

Submitted: May 16, 2012, Accepted: August 24, 2012 